FACTA UNIVERSITATIS

Series: Economics and Organization Vol. 17, No 4, 2020, pp. 385 - 396

https://doi.org/10.22190/FUEO200907028T

Review Paper

\title{
COMPARATIVE ANALYSIS OF DEVELOPMENTAL CONCEPTS OF SOCIAL ENTREPRENEURSHIP IN EUROPE AND THE USA
}

\author{
UDC 005.961:005.914.3]:364-3(4+73) \\ Miljana Talić*, Maja Ivanović-Đukić \\ University of Niš, Faculty of Economics, Serbia
}

\begin{abstract}
The paper presents a comparative analysis of the dominant theoretical concepts and models of social entrepreneurship development in continental Europe and the United States. The initial assumption of the paper was the differences in the model of capitalism that are present in these parts of the world, and the dominant theoretical concepts determine the differences in the form of manifestation of social entrepreneurial activity and the degree of population involvement in its implementation. Empirical research, with the aim of testing this assumption, was conducted on a sample of 50,000 social entrepreneurs from 25 countries. The results showed that there are no significant differences in the degree of involvement of the population in social entrepreneurial activity between Europe and the USA in the initial phase. In the operational phase, there are differences in the degree of involvement of the population in social entrepreneurship between Europe and the USA, but they are also present between Eastern and Western Europe, which means that they are not predominantly conditioned by theoretical concepts and models of social entrepreneurship, but by other factors.
\end{abstract}

Key words: social entrepreneurship, social enterprises, social innovations, start-up development phase, operational development phase of the SE.

JEL Classification: L31

Received September 07, 2020 / Accepted October 26, 2020 Corresponding author: Miljana Talić

* PhD Student at University of Nišs, Faculty of Economics

University of Niš, Faculty of Economics, Trg kralja Aleksandra 11, 18000 Niš, Serbia

E-mail: tmiljana@hotmail.com 


\section{INTRODUCTION}

Many countries had a problem with unemployment in the 1980s, which they could not solve with the existing mechanisms of social policy. New solutions needed to be found that would allow certain social groups to be introduced to the labor market (Certo \& Miller, 2008). As a possible solution to this problem, social enterprises began to be established.

Social enterprises were innovations in the public sector whose primary goal was primarily the care of socially vulnerable groups and the training of ,people who are disadvantaged in society and cannot be self-employed.“ (Raičević \& Glomazić, 2012, p. 7). Initially, social enterprises were founded and financed by the state, but very quickly members of civil society (citizens, informal groups, associations, etc.) self-organized. They independently created social enterprises in various legal forms to enable employment of people who are long-term unemployed and facilitate their inclusion in social flows (Hjorth, 2013; Monzon \& Chaves, 2017) or offer goods /services to the most vulnerable social groups, at relatively low prices or completely free and made it easier to overcome the institutional vacuum (Kolin \& Petrušić, 2008).

These individual initiatives involved finding new and original ideas for solving social problems, starting a business while providing all the necessary resources and bearing the risk of failure of such a job. In other words, they had all the elements of entrepreneurial activity, so they are beginning to be considered a "form of social entrepreneurship“ (Austin et al., 2006; Zahra et al., 2009; Elkington \& Hartigan, 2008).

The benefits of implementing an individual entrepreneurial initiative in the social sphere to solve social problems are being noticed by many international institutions, so they are starting to work on their promotion and development (Hjorth, 2013). These measures have resulted in the emergence of a large number of social enterprises and entrepreneurs (European Commission, 2013). The increase in the number of entrepreneurs with social goals in practice begins to draw the attention of scientists and „leads to the development of the theoretical concept of social entrepreneurship" (Johnson, 2000; Thompson et al., 2000).

As a concept that uses non-governmental organizations, market-based approaches to address social issues, social entrepreneurship is becoming increasingly accepted and is being applied worldwide. However, under the influence of the specific characteristics of the environment in which it develops, social entrepreneurship begins to take different forms in certain parts of the world. The most obvious differences occur in the development of social entrepreneurship in continental Europe, on the one hand, and the United States and the United Kingdom on the other. According to some authors, one can even speak of different models of social entrepreneurship (Bacq \& Janssen, 2011), while others agree that it is the same concept with certain variations (Hjorth, 2013).

The subject of this paper is to present the similarities and differences of the "European" and "American" model of social entrepreneurship through a comparative analysis of theoretical concepts and forms of manifestation of entrepreneurial activity in the social sphere. The aim of this paper is to examine whether there are significant differences in social entrepreneurship in these parts of the world.

The paper will first present the theoretical concepts of social entrepreneurship and the dominant schools that are present in the literature in Europe and the United States. Then, a comparative analysis of the practice of social entrepreneurship on both sides of the Atlantic will be done and the historical factors that shaped different conceptions of social entrepreneurship will be analyzed. Finally, using statistical methods, based on GEM data, 
it will be examined whether there are significant differences in the development of social entrepreneurial activity in Europe and the United States.

\section{LITERATURE REVIEW}

\subsection{Different theoretical concepts of social entrepreneurship in Europe and the USA}

Social entrepreneurship is a relatively new concept. In its theoretical explanation, there are significant differences between individual authors and institutions (Dacin et al., 2010). Differences in the explanation of the concept of social entrepreneurship appear, first of all, as a consequence of different understandings of entrepreneurship itself. As it is known, entrepreneurship can be viewed as a set of personal characteristics of individuals entrepreneurial spirit or as a set of the activities - entrepreneurial process (Ivanović-Đukić \& Radosavljević, 2019, p. 152). The first group of definitions explains social entrepreneurship from the aspect of personal characteristics of entrepreneurs. In that sense, a social entrepreneur is most generally defined as an individual who is able to find original ideas for solving social problems, provide the necessary resources and start a business in order to create value for society. The second group of definitions explains social entrepreneurship as a set of activities performed by a social entrepreneur. In this sense, social entrepreneurship is "a process of the value creation by combining resources in new ways" (Mair \& Marti, 2006, p. 37).

In addition, there are differences in the understanding of the essence of social entrepreneurship that have conditioned the emergence of: schools of social innovation and schools of social enterprises (Dees \& Battle Anderson, 2006). The School of Social Innovation arose from the theories of entrepreneurship developed by Josef Schumpeter (Schumpeter, 1934). The focus of this approach is innovation, i.e. "finding new and better means to solve social problems by the individual" (Dees \& Battle Anderson, 2006). Accordingly, a social entrepreneur can be defined as an innovator - a person who reforms or revolutionizes traditionally established models of creating social value in the direction of better use of resources to create greater social impact (Dees \& Battle Anderson, 2006; Peredo \& McLean, 2006; Sharir \& Lerner, 2006; Thompson et al., 2000; Nicholls \& Cho, 2006). While the primary goal of social entrepreneurial activity is the creation of added value for society by individuals and the introduction of sustainable changes for a society that take precedence over profit creation (Mair \& Marti, 2004; Weerawardena \& Sullivan Mort, 2006). The focus of this school is an individual, a social entrepreneur when they consider him an activist of social change. Thus, one person who is the bearer of social change, in Schumpeter's sense, is a key driver of social entrepreneurship even if a larger number of people can be involved in the creation of its organization (Dees \& Battle Anderson, 2006).

On the other hand, the school of social enterprises advocates the creation of organizations that will simultaneously achieve a social mission and generate income (Defourni \& Nissens, 2008 , p. 3). A social entrepreneur is a visionary who is able to identify opportunities from the environment and use the resources of a certain group of citizens to achieve "a social mission in an economically sustainable way and find innovative solutions to social problems of their community that are not adequately met by the local government" (Sullivan Mort et al, 2003; Dearlove, 2004; Roberts \& Woods, 2005; Sharir \& Lerner, 2006; Chell, 2007). The primary goal of social entrepreneurs' activities is to achieve a social mission (all social activities that can be non-profit) in an economically sustainable way, if the business performs activities that generate profit, it must be reinvested in solving social problems (Defourni \& Nissens, 
2008). Thus, according to this school, the primary role in the social economy is played by social enterprises (citizens' associations), while social entrepreneurs have a secondary role (Skoll, 2008).

The school of social enterprises is more accepted in Europe (Defourni \& Nissens, 2008, p. 3), while in the USA the school of social innovations is dominant. Interest in social enterprises in the United States is present only among non-profit organizations working on the establishment of social enterprises to use funds from international funds intended to finance these economic entities (Basq \& Janssen, 2011).

\subsection{Different practices of social entrepreneurship in Europe and the USA}

The development of social entrepreneurship in practice, in addition to dominant theoretical concepts, is greatly influenced by the institutional environment in which the activities of social entrepreneurs take place. The institutional environment is defined by legal regulations, administrative procedures, social policy and other measures implemented by the state. The institutional environment is specific for each country, so there are certain differences in the development of social entrepreneurship. The biggest differences appear in the concept and manner of development of social entrepreneurship in continental Europe on the one hand and the USA and the UK on the other, and they are largely conditioned by the characteristics of capitalism and the role of government. For example, the American model of capitalism is based on individual financial success, short-term financial gain, and media coverage. Not much attention is paid to economic differences. Poverty is seen as a reflection of laziness and irresponsibility. For these reasons, "unemployment benefits are very low, there is no compulsory health insurance or family allowance" (Albert, 1991). On the other hand, the model developed by Rhineland, which is present in continental Europe and Japan, gives greater importance to collective success, encourages long-term orientation and strives to reduce economic disparities in society. The European tradition considers the poor man a victim, not a culprit, so in most European countries there are a large number of forms of social assistance for the most economically vulnerable categories of the population and highly organized social insurance (Basq \& Janssen, 2011).

These two very different forms of capitalism lead to a different approach to the development of social entrepreneurship. As the governments of most countries in Europe implement a larger number of social policy measures to reduce social exclusion and poverty, all initiatives that help solve these problems are encouraged and supported. Social entrepreneurship is considered one of the priorities, so most countries provide various forms of financial and institutional assistance in the direction of its development (they push its development). Figure 1 shows the sources of income of social enterprises in Europe, where public funds play a significant role.

On the other hand, in the United States there are no direct state incentives or institutional measures to support the development of social entrepreneurship. It is considered an instrument for creating a welfare state. Through the media, work is done to raise public awareness of its role and importance, but its development is based on the voluntariness and individual initiatives of individuals (Dees \& Battle Anderson, 2006). Given that there are more incentives to start social entrepreneurial activity in Europe, it can be expected that a higher percentage of the population in Europe is involved in social entrepreneurial activity in the start-up phase compared to the USA and the UK. Therefore, our first hypothesis is: 
H1: Percent of people involved in social entrepreneurial activity in the start-up phase is higher in Europe, compared to the USA \& UK.

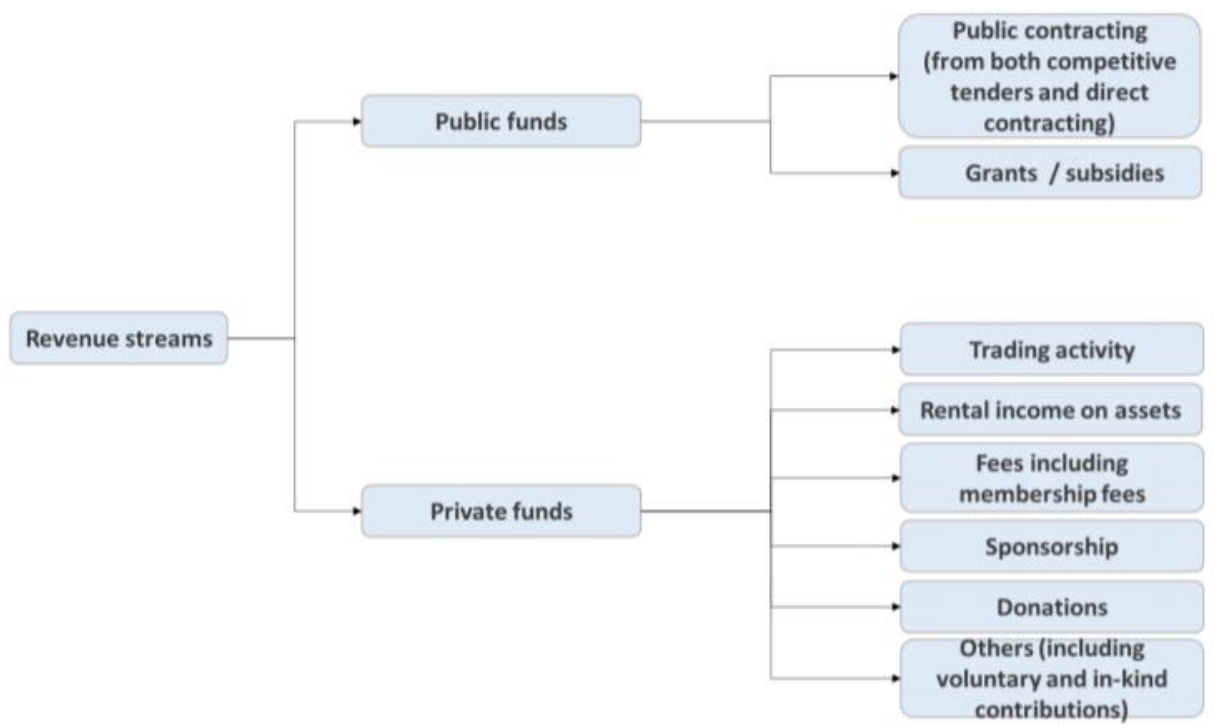

Fig. 1 Revenue streams for social enterprises in Europe

Source: European commission (2015) A map of social enterprises and their eco-systems in Europe. Luxembourg: Publications Office of the European Union

In addition to the characteristics of capitalism and the role of the Government, legal regulations and dominant theoretical concepts affect the characteristics of organizations as a form of manifestation of entrepreneurial activity with a social mission. According to the School of Social Innovation, which is dominant in the U.S., the legal form of an organization founded by a social entrepreneur can be different, and the organization itself can be nonprofit or for-profit. For Austin, Stevenson, and Wei-Skillern (2006), as well as for Mair and Marti (2004), "social entrepreneurship should not be limited to any specific legal form. According to these authors, the choice should rather be dictated by the nature of social needs and the amount of resources required." For Mair and Marti (2004) an important element is the entrepreneurial spirit that gives social initiatives their entrepreneurial nature. This perspective has resulted in the emergence of various hybrid organizational forms that can: be independent, generate profit, hire people and hire volunteers, adopt innovative strategies in search of social change," etc. "The advantages of these hybrid organizations include, among other things, higher market response rates, higher efficiency and innovation rates, as well as higher resource mobilization capacity" (Haugh, 2005; Dees \& Battle Anderson, 2006). Given that in the United States, social entrepreneurs have much greater opportunities to take advantage of opportunities from the market, it can be expected that a large percentage of initiated social jobs will survive the initial problems and move from the start-up to the operational phase. Our next hypothesis is:

$\mathrm{H} 2$ : Percent of people involved in social entrepreneurial activity in the operational phase is higher in the USA \& UK compared to Europe. 
In contrast, in Europe, the forms of entrepreneurial organizations and the legal forms they can receive are precisely defined. All organizations founded by social entrepreneurs are considered part of the so-called "third sector", are embedded in the field of social economy and can be: cooperatives, citizens' associations, foundations and mutual benefit societies. Two types of definitions can be found in European literature: conceptual and legal. International organizations as well as research centers have provided conceptual definitions. For example, the OECD defines a 'social enterprise' as "any private activity carried out in the public interest, organized by an entrepreneurial strategy, but whose main purpose is not to maximize profits but to achieve certain economic and social goals and which has the ability to bring innovative solutions to problems of Social Exclusion and Unemployment" (OECD, 1999). The European Commission's definition in the 2011 strategy paper entitled "Social Business Initiative" explains: rather than making a profit for its owners" (Brouard \& Lariviet, 2011). A comparative overview of these characteristics of social enterprises is given in Table 1.

Table 1 Comparative overview of social enterprise in the United States and Europe

\begin{tabular}{lll}
\hline & Europe & United States \\
\hline Mission & Creation of social value & Revenue generation \\
Types of Social Enterprise & Few & Many \\
Common Organizational Type & Association/Cooperative & Nonprofit \\
Focus & Human Services & All Nonprofit Activities \\
Activity of most SEs & Market based & Market based \\
Help from the government & Substantial & Insignificant \\
\hline
\end{tabular}

Source: Authors' work based on a literature review

EMES network researchers have developed a common definition of a social enterprise that should fit into the different national contexts of individual EU countries. They list the criteria that an organization needs to meet in order to be considered a social enterprise. On the one hand, "four criteria are stated that reflect the economic and entrepreneurial dimensions of the organization: (1) continuous activity of production and sale of goods and/or services; (2) a high degree of autonomy; (3) a significant level of economic risk; and (4) the minimum amount of work paid." On the other hand, five criteria are listed that unite the social character of an entrepreneurial initiative: "(1) an explicit goal for the benefit of the community; (2) an initiative launched by a group of citizens; (3) decision-making power that is not based on capital and ownership; (4) participatory nature including all actors of the activity; and (5) limited profit distribution" (Defourni \& Nissens, 2008).

Using this definition as a starting point for identifying social enterprises, significant differences in the number of social enterprises in European countries can be observed. Table 2 provides an overview of the estimated number of social enterprises in the EU and non-EU countries, the number of social enterprises per million inhabitants, as well as the estimated number of employees in these enterprises. 
Table 2 Estimated number of social enterprise in EU and non-EU countries

\begin{tabular}{|c|c|c|c|c|c|}
\hline & Country & Year & $\begin{array}{c}\text { Estimated } \\
\text { number of SEs }\end{array}$ & $\begin{array}{l}\text { Number of SEs } \\
\text { per million } \\
\text { inhabitants }\end{array}$ & $\begin{array}{l}\text { Estimated } \\
\text { number of } \\
\text { employees }\end{array}$ \\
\hline \multirow{27}{*}{$\begin{array}{l}\text { EU } \\
\text { countries }\end{array}$} & Austria & 2015 & Approx. 1,535 & Approx. 174 & N.A. \\
\hline & Belgium & 2017 & 18,004 & 1,530 & 572,914 \\
\hline & Bulgaria & $2015-2017$ & Approx. 3,700 & Approx. 525 & 26,000 \\
\hline & Croatia & 2018 & 526 & 128 & N.A. \\
\hline & Cyprus & 2017 & 190 & 22 & N.A. \\
\hline & Czech Republic & 2018 & 3,773 & 356 & N.A. \\
\hline & Denmark & 2018 & 411 & 71 & N.A. \\
\hline & Estonia & 2016 & 121 & 92 & 1,603 \\
\hline & Finland & 2018 & 1,181 & 214 & Approx. 52,500 \\
\hline & France & $2015-2017$ & Approx. 96,603 & 1,414 & $>1,187,249$ \\
\hline & Germany & 2017 & 77,459 & 936 & N.A. \\
\hline & Greece & 2019 & 1,148 & 107 & N.A. \\
\hline & Hungary & 2016 & 15,855 & 1,621 & 72,642 \\
\hline & Ireland & 2009 & 3,376 & 699 & $>25,000$ \\
\hline & Italy & 2017 & 102,461 & 1,694 & 894,800 \\
\hline & Latvia & 2018 & Approx. 200 & Approx. 103 & N.A. \\
\hline & Lithuania & $2016-2017$ & 3,476 & 1,237 & N.A. \\
\hline & Luxembourg & $2017-2018$ & 928 & 1,546 & 24,055 \\
\hline & Malta & 2018 & $31-62$ & $65-130$ & N.A. \\
\hline & Netherlands & $2015-2016$ & $5,000-6,000$ & $290-350$ & $65,000-80,000$ \\
\hline & Poland & 2016-2019 & 29,535 & 768 & 428,700 \\
\hline & Portugal & 2013 & 7,938 & 771 & 145,734 \\
\hline & Romania & $2015-2017$ & 6,317 & 323 & 17,117 \\
\hline & Slovakia & 2014 & 3,737 & 687 & N.A. \\
\hline & Slovenia & 2017 & 1,393 & 674 & 15,063 \\
\hline & Spain & 2017 & 9,680 & 208 & $>91,500$ \\
\hline & Sweden & $2009-2016$ & Approx. 3,000 & Approx. 296 & N.A. \\
\hline \multirow{8}{*}{$\begin{array}{l}\text { non-EU } \\
\text { countries }\end{array}$} & Albania & 2018 & 379 & 132 & $2,000-2,500$ \\
\hline & Iceland & 2017 & 258 & 740 & 1,488 \\
\hline & Montenegro & 2018 & 150 & 241 & $<500$ \\
\hline & North Macedonia & $2013-2015$ & 551 & 266 & N.A. \\
\hline & Norway & 2016 & 250 & 47 & N.A. \\
\hline & Serbia & 2012 & 411 & 59 & 4,273 \\
\hline & Turkey & 2016-2018 & 1,776 & 22 & N.A. \\
\hline & United Kingdom & $2007-2017$ & 30,753 & 464 & 353,357 \\
\hline
\end{tabular}

Legal definitions cite the national governments of each state to establish clear criteria for entities that can be considered social enterprises, and they vary from country to country (Basq \& Janssen, 2011). Also, organizations and instruments of support for their development differ. However, there are some elements that are present in most EU countries that provide the basic infrastructure for the development of social entrepreneurship. First, there is legislation in the field of social entrepreneurship. Legal regulations define the most important conditions that should be met by the subjects of the social economy, their goals, business principles, forms of organization, establishment procedures, etc. Then, in most 
countries, state bodies (ministries, councils, etc.) have been formed that are responsible for implementing measures to create a stimulating environment for the development of social entrepreneurship. These bodies work on strategies and implement policies for the development of social entrepreneurship, work on promoting and supporting social enterprises (through media promotion of the role and importance of social enterprises, providing better access to funding sources, creating institutions supporting social enterprises, etc.). Also, the activities of non-governmental organizations that are active in the field of social economy are stimulated. All these measures lead to the creation of a stimulating environment for the development of social entrepreneurship (Mitrović \& Mitrović, 2019).

\section{MetHODOLOGY}

\subsection{Sample, model and variables}

GEM (Global Entrepreneurship Monitor) data from 2015 (analysis of social entrepreneurship was performed at that time, while other reports do not contain this data) are used for the analysis (Bosma et al., 2016). Our sample includes a total of 25 countries: of which 10 are Eastern European countries, 13 are Western European countries, the UK and the USA. In accordance with the standard GEM methodology, each country provides answers for at least 2,000 entrepreneurs, so that our sample includes over 50,000 social entrepreneurs. Respondents of the GEM database consist of individuals aged 18-64 years.

According to GEM, a social entrepreneur is defined as "an individual who initiates or currently leads any type of activity, organization or initiative that has a particular social, environmental or common goal" (Bosma et al., 2016). There are two phases in the development of social entrepreneurial activity: start-up phase and operational phase. The start-up phase implies the initial entrepreneurial activity and refers to new companies (up to 3.5 years old). This phase is characterized by a number of challenges associated with starting a new business, so many businesses fail in the first few months of business and do not reach the next phase. Those companies that have existed for more than three and a half years are in the operational phase. This multi-stage procedure is useful for assessing the state of entrepreneurship at various points.

In order to examine whether there are statistically significant differences in the degree of population involvement in social entrepreneurship in the USA and Europe, a Multivariable Analysis of Variance (MANOVA) was performed. The variables in the model were the percentage of those involved in SE at individual stages in different parts of the world.

\subsection{Results and Discussion}

The results of descriptive statistics are shown in Table 3.

It can be seen from the table that the average values for the degree of involvement of the population in social entrepreneurship in the observed regions are approximately uniform. In the start-up phase, the average value in Western Europe is $4.05 \%$, in Eastern Europe $3.85 \%$, and in the USA \& United Kingdom $4 \%$. The highest degree of involvement is in Hungary (9.7\%) and the lowest in Bulgaria 0.6\%. Eastern European countries have the largest deviations from the average. 
Table 3 Descriptive statistics

\begin{tabular}{lrrrr}
\hline & Mean & SD & Min. & Max \\
\hline Eastern Europe & & & & \\
$\quad$ Involved in SE, start-up phase & 3.28 & 6.18 & 0.6 & 9.7 \\
$\quad$ Involved in SE, operational phase & 3.14 & 2.23 & 0.7 & 6.9 \\
$\quad$ Involved in social goal, start-up phase & 1.44 & 3.78 & 0.3 & 5.8 \\
$\quad$ Involved in social goal, operational phase & 1.64 & 2.18 & 0.3 & 3.9 \\
\hline Western Europe & & & & \\
$\quad$ Involved in SE, start-up phase & 4.05 & 4.29 & 0.8 & 7.4 \\
$\quad$ Involved in SE, operational phase & 4.90 & 6.3 & 1.5 & 10.3 \\
$\quad$ Involved in social goal, start-up phase & 2.39 & 1.13 & 0.5 & 3.2 \\
$\quad$ Involved in social goal, operational phase & 3.13 & 2.37 & 0.9 & 5.5 \\
\hline SAD \&United Kingdom & & & & \\
$\quad$ Involved in SE, start-up phase & 4 & 2.85 & 2.3 & 5.7 \\
$\quad$ Involved in SE, operational phase & 6.3 & 3.83 & 4.2 & 8.4 \\
$\quad$ Involved in social goal, start-up phase & 2.4 & 2.21 & 1.1 & 3.7 \\
Involved in social goal, operational phase & 4 & 3.33 & 2.5 & 5.5
\end{tabular}

Source: Authors' work based on: Bosma et al. (2016) Global Entrepreneurship Monitor 2015 to 2016 : Special Report on Social Entrepreneurship. Global Entrepreneurship Research Association.

In the operational phase, the average involvement in Eastern Europe is 3.13\%, in Western Europe $3.9 \%$, in the USA \& United Kingdom 6.3\%. The highest degree of inclusion is in Luxembourg (10.3\%), and the lowest in Bulgaria $0.7 \%$.

In order to check whether there are statistically significant differences in the degree of involvement of the population in social entrepreneurship in certain phases, MANOVA was done. The results are shown in Table 4.

Table 4 Degree of population involvement in social entrepreneurship in Europe and the USA

\begin{tabular}{|c|c|c|c|c|c|c|c|}
\hline & $\begin{array}{l}\text { Eastern } \\
\text { Europe }\end{array}$ & $\begin{array}{l}\text { Western } \\
\text { Europe }\end{array}$ & US \& UK & $\mathrm{F}$ & $\mathrm{p}$-value & $\begin{array}{l}\text { Partial } \\
\text { Eta Sq. }\end{array}$ & $\begin{array}{c}\text { Bonferroni } \\
\text { Test }\end{array}$ \\
\hline $\begin{array}{l}\text { Involved in SE, } \\
\text { start-up phase }\end{array}$ & 3.28 & 4.05 & 4 & .59 & .623 & .01 & $\mathrm{NS}^{*}$ \\
\hline $\begin{array}{l}\text { Involved in SE, } \\
\text { operational phase }\end{array}$ & 3.14 & 4.90 & 6.3 & 4.46 & .005 & .08 & $1-2,1-3,2-3$ \\
\hline $\begin{array}{l}\text { Involved in social goal, } \\
\text { start-up phase }\end{array}$ & 1.28 & 1.75 & 2.4 & .47 & .562 & .02 & $\mathrm{NS}^{*}$ \\
\hline $\begin{array}{l}\text { Involved in social goal, } \\
\text { operational phase }\end{array}$ & 1.46 & 2.49 & 4 & 4.05 & .008 & .07 & $1-3,2-3$ \\
\hline
\end{tabular}

Source: Author's own work

As it can be seen, there are no statistically significant differences in the degree of population involvement in social entrepreneurial activity in the start-up phase between Eastern Europe, Western Europe and the US \& UK. Our first hypothesis has not been proven. When it comes to the operational phase, there are significant differences, both between Europe and the US \& UK, and between Eastern and Western Europe. This result points to the conclusion that theoretical concepts of SE (Dacin et al., 2010) and characteristics of capitalism (Bacq \& 
Janssen, 2011) are not the key cause of differences in the involvement of population in social entrepreneurship in Europe vs. USA. The analysis of the factors that predominantly influence the development of social entrepreneurship will be the subject of future research.

\section{CONCLUSION}

The field of social entrepreneurship is characterized by great diversity from the point of view of defining the concept and its application in practice. In addition to discrepancies in different regions, the distinctions are particularly pronounced in the understanding of this concept in different countries and institutional contexts. This differentiation is especially visible when comparing this type of entrepreneurship in Europe and the USA.

Despite the unique understanding of the essence of the concept of social entrepreneurship, there are significant differences in its development in Europe and the United States. Differences appear in the theoretical explanation and understanding of the essence and in the models of its development in practice. The paper explains the "School of Social Innovations" and the "School of Social Enterprises", as theoretical concepts that explain the essence of social entrepreneurship from different aspects. Also, the differences that occur in the way the concept is applied in Europe and the USA are explained. Comparing social enterprises, it was found that in many areas where the United States has difficulties with social entrepreneurship, Europe has a better solution and vice versa, which leaves space for mutual learning.

However, our empirical research on a sample of 25 countries and over 50,000 social entrepreneurs showed that significant differences in the degree of involvement of the population in social entrepreneurial activity do not exist in the initial phase. In the operational phase, there are differences in the degree of involvement between Europe and the United States, but differences also exist between Eastern and Western Europe, which means that they are not predominantly conditioned by theoretical concepts and development models of SE, but by some other factors.

\section{REFERENCES}

Albert, M. (1991). Capitalisme contre capitalisme. Paris: Editions du Seuil.

Austin, J., Stevenson, H., \& Wei-Skillern, J. (2006). Social and commercial entrepreneurship: Same, different, or both?. Entrepreneurship Theory \& Practice, 30(1), 1-22.

Bacq, S., \& Janssen, F. (2011). The multiple faces of social entrepreneurship: A review of definitional issues based on geographical and thematic criteria. Entrepreneurship \& Regional Development, 23(5-6), 373-403.

Bosma, S. N., Schøtt, T., Terjesen, A. S., \& Kew, P. (2016). Global Entrepreneurship Monitor 2015 to 2016 : Special Report on Social Entrepreneurship. Global Entrepreneurship Research Association.

Brouard, F., \& Larivet, S. (2011). Essay of Clarifications and Definitions of the Related Concepts of Social Enterprise, Social Entrepreneur and Social Entrepreneurship. In: Fayolle, A. \& Matlay H. (2011). Handbook of Research on Social Entrepreneurship. Cheltenham: Edward Elgar, (pp. 29-56).

Certo, S., \& Miller, T. (2008). Social entrepreneurship: Key issues and concepts. Business Horizons, 51(4), 267-271.

Chell, E. (2007). Social enterprise and entrepreneurship - Towards a convergent theory of the entrepreneurial process. International Small Business Journal, 25(1), 5-26.

Dacin, P. A., Dacin, M. T., \& Matear, M. (2010). Social entrepreneurship: Why we don't need a new theory and how we move forward from here. Academy of Management Perspectives, 24(2), 36-56.

Dearlove, D. (2004). Interview: Jeff Skoll. Business Strategy Review, 15(2), 51-53.

Dees, G., \& Battle Anderson, B. (2006). Framing a theory of social entrepreneurship: Building on two schools of practice and thought. ARNOVA Occasional Paper Series, 1(3), 39-66. 
Defourny, J., \& Nyssens, M. (2008). Social Enterprise in Europe: Recent Trends and Developments. Social Enterprise Journal, 4(3), 202-228.

Elkington, J., \& Hartigan, P. (2008). The power of unreasonable people: How social entrepreneurs create markets that change the world. Boston: Harvard Business Press.

European Commission (2013). Social Economy and social entrepreneurship, Social Europe Guide, 4. Luxembourg: Publications Office of the European Union

European commission (2015). A map of social enterprises and their eco-systems in Europe. Luxembourg: Publications Office of the European Union

European Commission (2020). Social enterprises and their ecosystems in Europe. Comparative synthesis report. Authors: Carlo Borzaga, Giulia Galera, Barbara Franchini, Stefania Chiomento, Rocío Nogales and Chiara Carini. Luxembourg: Publications Office of the European Union. Available at https://europa.eu/!Qq64ny

Haugh, H. (2005). A research agenda for social entrepreneurship. Social Enterprise Journal, 1(1), 1-12.

Hjorth, D. (2013). Public Entrepreneurship: Desiring Social Change, Creating Sociality. Entrepreneurship and Regional Development, 25(1-2), 34-51.

Ivanović Đukić, M., \& Radosavljević, M. (2019). Preduzetnički proces [Entrepreneurial process]. Ekonomski fakultet Niš.

Johnson, S. (2000). Literature review on social entrepreneurship. Canadian Centre for Social Entrepreneurship.

Kolin, M., \& Petrušić, N. (2008). Socijalna preduzeća i uloga alternativne ekonomije u procesima Evropskih integracija [Social enterprises and the role of alternative economy in the processes of European integration]. Beograd: Evropski pokret u Srbiji.

Mair, J., \& Marti, I. (2004). Social entrepreneurship: What are we talking about? A framework for future research (Working Paper 546). Barcelona: IESE Business School. University of Navarra.

Mair, J., \& Marti, I. (2006). Social entrepreneurship research: A source of explanation, prediction, and delight. Journal of World Business, 41(1), 36-44.

Mitrović, J., \& Mitrović, V. (2019). The development of social entrepreneurship and the perspective of its further affirmation in the overall development of Serbia. Anali Ekonomskog fakulteta u Subotici, (42), 81-97.

Monzón, J. L., \& Chaves, R. (2017). Recent evolutions of the Social Economy in the European Union. Bruxelles: European Economic and Social Committee.

Nicholls, A., \& Cho, A. H. (2006). Social Entrepreneurship: The Structuration of a Field. In: Nicholls, A. (ed.) Social Entrepreneurship: New Models of Sustainable Social Change (pp. 99-118). Oxford: Oxford University Press.

OECD (1999). Social enterprises. Paris: OECD.

Peredo, A. M., \& McLean, M. (2006). Social entrepreneurship: A critical review of the concept. Journal of World Business, 41(1), 56-65.

Raičević, V., \& Glomazić, R. (2012). Značenje i oblici socijalnog preduzetništva [The meaning and forms of social entrepreneurship]. Beograd: Friedrich Ebert Stiftung.

Roberts, D., \& Woods C. R. (2005). Changing the world on a shoestring: The concept of social entrepreneurship. University of Auckland. Business Review, 19(1), 45-51.

Schumpeter, J. A. (1934). The Theory of Economic Development: An Inquiry into Profits, Capital, Credit, Interest and the Business Cycle. Cambridge MA: Harward Univercity Press.

Sharir, M., \& Lerner, M. (2006). Gauging the success of social ventures initiated by individual social entrepreneurs. Journal of world business, 41(1), 6-20.

Skoll, J. (2008). In: Nicholls, A.. (ed.) Preface to social entrepreneurship: New models of sustainable social change. Oxford: Oxford University Press.

Sullivan Mort, G., Weerawardena, J., \& Carnegie, K. (2003). Social entrepreneurship: Towards conceptualization. International Journal of Entrepreneurship Behavior \& Research, 8(1), 76-88.

Thompson, J. L., Alvy, G., \& Lees, A. (2000). Social entrepreneurship - A new look at the people and the potential. Management Decision, 38(5), 328-338.

Weerawardena, J., \& Sullivan Mort, G. (2006). Investigating social entrepreneurship: A multidimensional model. Journal of World Business, 41(1), 21-35.

Zahra, S. A., Gedajlovic, E., Neubaum, D. O., \& Shulman, J. M. (2009). A Typology of Social Entrepreneurs: Motives, Search Processes and Ethical Challenges. Journal of Business Venturing, 24(5), 519-532. 


\section{KOMPARATIVNA ANALIZA RAZVOJINIH KONCEPATA SOCIJALNOG PREDUZETNIŠTVA U EVROPI I SAD}

U radu je izvršena komparativna analiza dominantnih teorijskih koncepata i modela razvoja socijalnog preduzetništva u kontinentalnoj Evropi i SAD. Polazna pretpostavka rada bile su razlike u modelu kapitalizma koje su prisutne u ovim delovima sveta, a dominantni teorijski koncepti uslovljavaju razlike u obliku manifestacije socijalne preduzetničke aktivnosti i stepenu uključenosti stanovništva u njenoj implementaciji. Empirijsko istraživanje, sa ciljem testiranja ove pretpostavke, sprovedeno je na uzorku od 50.000 socijalnih preduzetnika iz 25 zemalja. Rezultati su pokazali da ne postoje značajne razlike u stepenu uključenosti stanovništva u socijalnu preduzetničku aktivnost između Evrope i SAD-a u početnoj fazi. U operativnoj fazi se javljaju razlike u stepenu uključenosti stanovništva u socijalno preduzetništvo između Evrope i SAD, ali su one takođe prisutne između Istočne $i$ Zapadne Evrope, što znači da nisu dominantno uslovljene teorijskim konceptima $i$ modelom razvoja socijalnog preduzetništva, već nekim drugim faktorima.

Ključne reči: socijalno preduzetništvo, socijalna preduzeća, socijalne inovacije, start-up faza razvoja, operativna faza razvoja $S E$ 